\title{
Disclosure of financial instruments according to International Accounting Standards: empirical evidence from Brazilian companies
}

\author{
Rodrigo Fernandes Malaquias ${ }^{\dagger}$ \\ Fundação Getulio Vargas \\ Sirlei Lemes ${ }^{\Omega}$ \\ Universidade Federal de Uberlândia
}

\begin{abstract}
This article analyzes the level of disclosure of financial instruments in the financial statements of Brazilian companies in light of the requirements of the International Accounting Standards Board (IASB). We examined the annual reports of a sample of 24 nonfinancial firms provided to the Brazilian and the American capital markets for the years from 2002 to 2006. The main results are that the reports to the Brazilian market have an average disclosure level that it statistically inferior to the level of the reports released to the American market, and firms in regulated sectors, firms with a longer history of issuing ADRs and larger firms show higher levels of disclosure.
\end{abstract}

Keywords: Disclosure. IFRS 7; financial instruments.

${ }^{\dagger}$. PhD in Business Administration from FGV-SP Institution: Assistant professor at University of Uberlândia

Address: Av.João Naves de Àvila, 2121, Bloco F, Sala 1F-213, Bairro Santa Mônica, Uberlândia - MG Brazil

E-mail: rodrigofmalaquias@yahoo.com.br Telephone: (34) 3239-4176
$\Omega \mathrm{PhD}$ in Accounting and Control from USP

Institution: Associate professor at the School of Accounting of Uberlândia Federal University.

Address: Avenida Naves de Ávila, 2121, Bloco F, Sala 1F-201,

Santa Mônica, Uberlândia - MG - Brazil

E-mail: sirlemes@uol.com.br

Telephone: (34)3230-9474

Note from the Editor: This article was accepted by Bruno Funchal.

\section{(cc) $\mathrm{EY}$}

This article has a Creative Commons License - Attribution 3.0 Not Adapted. 


\section{INTRODUCTION}

he level of disclosure of companies in their accounting reports has been a fertile area for academic studies. The disclosure of accounting information, for instance, helps reduce information asymmetry, sheds light on the volatility of stock returns and can also be an indicator for both domestic and foreign investors in making their choices (Levine, Loayza \& Beck, 2000; Love, 2003). Therefore, the disclosure standards play an important role in the efficiency of the capital market. The International Accounting Standards Board (IASB) at the global level and the Accounting Pronouncements Committee (Comitê de Pronunciamentos Contábeis - CPC) in Brazil are examples of bodies responsible for issuing accounting standards on a wide range of matters, including the minimum mandatory disclosure of information.

The study of international accounting standards in the case of Brazil is appropriate particularly because in 2007 the Brazilian Securities Commission (Comissão de Valores Mobiliários - CVM) issued a new rule requiring listed Brazilian companies to present their consolidated financial statements according to the standards issued by the IASB. As part of this convergence process, a Memorandum of Understanding (IASB/CFC/CPC, 2010) was signed among the IASB, CPC and the Federal Accounting Board (Conselho Federal de Contabilidade-CFC).

Among the standards issued by the IASB, here we focus on International Financial Reporting Standard no. 7 (IFRS 7), which covers disclosure of financial instruments. One of the reasons for this choice is the difficulty faced by firms to implement the specific accounting requirements for the treatment of financial instruments, especially derivatives (Wallace \& Williams, 2002; Bhamornsiri \& Schroeder, 2004). Furthermore, transactions with financial instruments, if not properly managed, can cause serious losses to companies (Aguiar \& Hirano, 2003; Hernandez, 2003; Valor On-Line, 2011), so shareholders need sufficient information on these transactions, an aspect where Brazil is deficient (Costa Júnior, 2003; Murcia \& Santos, 2009).

The disclosure of financial instruments by Brazilian companies has been investigated by other authors, such as Costa Júnior (2003) and Darós \& Borba (2005), but none of them have focused on that disclosure according to the rules issued by the IASB. The results obtained by those researchers indicate that the level of disclosure of Brazilian firms in light of the requirements of regulators such as the CVM and the FASB (Financial Accounting Standards 
Board) is not satisfactory, and that the reports released to the American capital market are more complete than those provided to the Brazilian market.

Based on the context of adaptation of Brazilian firms to international accounting standards and the different treatment and disclosure of information between distinct capital markets, our objectives are to analyze the level of disclosure of financial instruments supplied by Brazilian companies in their accounting reports and to identify possible characteristics/factors related to a greater/lesser level of disclosure.

Studies of this disclosure in the context of Brazilian firms is particularly interesting because of the better possibilities of cross-sectional variations in the levels of disclosure (Lopes \& Alencar, 2010), a situation that can be different in more developed capital markets. Therefore, an estimate of the distance between what is required by the IASB standards and what companies actually do can: i) shed light on what can be expected in the first years after convergence; and ii) serve as an indicator of what should be done so that firms' accounting reports are nearer to satisfying the international requirements of the IASB. For this purpose, the data analyzed in this article, covering the pre-convergence period (2002 to 2006), can serve as the base to address those issues.

We chose nonfinancial companies for this study because the trading of certain financial instruments, such as derivatives, is not part of their operational context in Brazil. This same exclusion has been made in other studies of disclosure practices, such as Naser \& Nuseibeh (2003), Akhtaruddin (2005) and Alsaeed (2006).

\section{THE RELEVANCE OF ACCOUNTING INFORMATION}

Lopes \& Martins (2005, p. 31) state that as external users, "investors do not have the same level of information as company managers, so they need independent instruments to evaluate the real situation." Therefore, when a company does not provide complete disclosure in its reports, the information that reaches external users can paint a picture of less risk than that really faced by the firm, among other problems (Lopes \& Lima, 1998, p. 9). Ceteris paribus, the greater the level of disclosure, the lower investors' uncertainty will be in their decisions (Poshakwale \& Courtis, 2005). This has been long recognized, as reflected in the statement of Horngren (1957, p. 598): "It is probable that the analyst would be better able to make intelligent decisions concerning securities if he should receive corporate information in bigger and better quantities and qualities." 
The incomplete supply of information causes information asymmetry (Leuz \& Verrecchia, 2000), which directly impacts the basic objective of accounting. Iudícibus, Martins \& Carvalho (2005, p. 11) stress that "diminishing or counteracting information asymmetry is one of the most important tasks of modern accounting, which in this aspect [...], has reached the stature of a science." The commitment of firms to better disclosure levels reduces the severity of information asymmetry between the firm on the one hand and its shareholders and potential investors on the other (Leuz \& Verrecchia, 2000). Specifically, the quality of accounting information has positive effects on the perception of market participants about the distribution of future cash flows of the company, also impacting decisions based on the forecast cash flows (Lambert, Leuz \& Verrecchia, 2007).

Bushman, Piotroski \& Smith (2004) point out that for listed corporations, transparency means equal availability of information. According to Lima et al. (2006, p. 548), "shareholders expect management to prepare the most transparent accounting statements possible." Therefore, the themes of accounting disclosure and transparency also involve the theme of corporate governance, because one of the four pillars of good governance is the principle of transparency, whereby besides the duty to inform, managers must cultivate a desire to inform (IBGC, 2003).

According to Coffee (1999) and Khanna, Palepu \& Srinivasan (2004), there is a tendency to create a relatively uniform governance structure to be adopted worldwide by firms. This structure is based on the converging orientations, which according to those authors can be divided into two groups: i) legal convergence (e.g., requiring stricter application of legal rules); and ii) functional convergence (e.g., requiring the adoption of the accounting principles recommended by the IASB).

For Malacrida \& Yamamoto (2006, p. 69), transparency, and consequently disclosure "is one of the pillars of corporate governance, with great emphasis on all the reflections on the subject and also present in the majority of existing codes." In this same line, Ho \& Wong (2001, p. 142) consider that "Transparency is the biggest indicator of the standard of corporate governance in the economy"

Given the importance of the transparency of accounting information - enabled by disclosure - it is relevant to study this disclosure by public corporations. 


\section{DISCLOSURE OF FINANCIAL INSTRUMENTS}

The business environment is one of inherent risks. According to PWC (2000), these risks can come from the specific market segment, changes in financing opportunities, contracts for future delivery, among many other aspects. One of the crucial sources of risk is that from financial markets. According to Saito and Schiozer (2004, p. 1), "the volatility of the financial markets can affect firms significantly, even causing them to fail." To protect against this volatility, such risks can be managed through the use of derivative financial instruments. "Derivatives provide an effective and inexpensive way for final users to protect against and manage the risks inherent to interest rates, commodity prices or exchange rates" (Carvalho, 2002, p. 38).

Due to the characteristics of the accounting treatment of firms' commitments, it may not be possible to account for them, and hence to disclose them in the traditional accounting statements, such as the balance sheet. This leads to so-called off-balance-sheet items, typical examples of which are commitments for future purchase or sale of goods or assets. According to Lopes \& Carvalho (1999, p. 6), the absence of recognition of financial instruments on the balance sheet is a "very serious problem, since external users of accounting information do not have access the volume of transactions of the organization analyzed through its accounting statements."

However, even though these transactions cannot be disclosed in the body of the balance sheet, the company should reveal them in the notes, so that external users can make more informed decisions. In this respect, the accounting standard- setting entities play a key role in requiring firms to comply with minimum disclosure levels.

According to international accounting standards, the disclosure of financial instruments is regulated by IFRS 7, as mentioned before. Its objective is to require firms to provide information in their financial reports to enable users to assess: i) the significance of financial instruments to the financial position and performance of the firm; and ii) the nature and extent of the risks arising from financial instruments to which the firm is exposed during the period and on the reporting date, and how the firm manages those risks. Among the specific requirements are minimum levels of disclosure of credit risk, liquidity risk and market risks (IASB, 2008b). The requirements apply to both qualitative and quantitative aspects of disclosure, which together should provide a fair overview of the use of financial instruments by the firm and its exposure to the risks resulting therefrom. 
Although Brazilian standards until 2007 were not as detailed as international standards regarding disclosure of financial instruments, CVM Instruction 235 of 1995 did require listed companies to reveal the market value of their financial instruments along with the criteria and premises used to calculate this value, together with the policies for use and control of the transactions and the risks involved. In the Study of Brazilian Accounting Practices and International Accounting Standards (Estudo Sobre as Práticas Contábeis Brasileiras e as Normas Internacionais de Contabilidade), available at the CVM's website (CVM, 2011), specifically in Topic 19 - Financial Instruments, there is a chart comparing the main similarities and differences between the two sets of rules on financial instruments. Chart 1 below summarizes the most relevant of these points.

\begin{tabular}{|l|l|}
\hline \multicolumn{1}{|c|}{ Brazilian Standards } & \multicolumn{1}{c|}{ International Standards } \\
\hline $\begin{array}{l}\text { No categories are specified for segregation of } \\
\text { financial instruments. }\end{array}$ & $\begin{array}{l}\text { The values of financial instruments should be } \\
\text { booked observing classification into five } \\
\text { categories. }\end{array}$ \\
\hline $\begin{array}{l}\text { There are no rules on disclosure of other revenues } \\
\text { and expenses specifically related to financial } \\
\text { instruments }\end{array}$ & $\begin{array}{l}\text { Firms should disclose in the financial statements of } \\
\text { notes on revenues, expenses, losses and gains in } \\
\text { the five categories established by the standard. }\end{array}$ \\
\hline $\begin{array}{l}\text { The international accounting standards are much } \\
\text { more detailed regarding the aspects that should be } \\
\text { disclosed. }\end{array}$ & $\begin{array}{l}\text { Firms should disclose the market value of each } \\
\text { class of financial assets and liabilities in a form } \\
\text { that allows comparison with the accounting value. }\end{array}$ \\
\hline
\end{tabular}

Chart 1: Some points of divergence between Brazilian and international accounting standards on disclosure of financial instruments

Source: CVM (2011).

\section{QUALITY OF DISCLOSURE AND ITS DETERMINANTS}

Discussion of the quality of the disclosure of information in firms' accounting reports is not recent (Horngren, 1957). A consultation of the articles previously published along with the standards issued recently in Brazil on the treatment of transactions with financial instruments (CVM, 2008a, for example) gives an idea of the disparities in the requirements on disclosure according to Brazilian, American and international standards. We next briefly review the literature in this respect.

Darós, Borba \& Abreu (2005), comparing the disclosure of transactions with derivatives in the accounting reports in the Brazilian and American markets, found significant differences, with the reports published in the United States supplying more complete information than those in Brazil, even when examining Brazilian firms with securities traded in both markets. In a similar study, Darós \& Borba (2005) also indicated that Brazilian companies do not disclose in Brazil the minimum information on investment and valuation of derivatives and control of risk (credit, market and currency risks). Based on this scenario, it is 
reasonable to expect that dual-listed Brazilian firms will tend to be stingier about disclosing information in their accounting reports to the Brazilian market than those to the American market, with the latter being nearer to meeting the minimum disclosure levels recommended by international standards.

Since some Brazilian firms do not fully meet the requirements already issued by the CVM for disclosure of financial instruments (Costa Júnior, 2003; Darós \& Borba, 2005; Múrcia \& Santos, 2009) and the disclosure of Brazilian companies is different in different capital markets, we formulated the first hypothesis: Hypothesis $1\left(\mathrm{H}_{1}\right)-$ The index of the disclosure of financial instruments of Brazilian companies in the Brazilian market is statistically different than that of their disclosure to the American market.

There are arguments that larger firms tend to have better disclosure levels (Horngren, 1957; Leuz \& Verrecchia, 2000). One of the explanations is that larger organizations have more complete information systems, allowing them to generate more detailed information at lower unit cost (Lopes \& Rodrigues, 2007). Therefore, based on this argument and previous empirical findings (Alsaeed, 2006; Lopes \& Rodrigues, 2007), we expect to find a positive relationship between firm size and the level of disclosure, leading to our second hypothesis: Hypothesis $2\left(\mathrm{H}_{2}\right)$ - There is a positive relationship between firm size and level of disclosure of financial instruments.

Because one of the pillars of good corporate governance practices is transparency, it is reasonable to expect firms with securities listed for trading in markets segments that require enhanced governance to have better levels of disclosure than firms not so listed. Gallon (2006) found a positive association between the disclosure practices present in management reports and participation of companies in differentiated corporate governance levels. For Brazilian financial institutions, Costa, Goldner \& Galdi (2007) showed that the participation in one of the three segments of the São Paulo Stock Exchange (BM\&FBovespa) requiring enhanced corporate governance is a factor influencing disclosure levels. This leads to our third hypothesis: Hypothesis $3\left(\mathrm{H}_{3}\right)$ - Adherence to one of the enhanced governance segments of the BM\&FBovespa is positively related to the disclosure index.

According to Lopes \& Rodrigues (2007), some economic sectors can have greater institutional pressures for disclosure of information than others. In particular, companies in regulated sectors face requirements to reveal accounting information from the respective regulatory agencies that are typically more stringent than those required of firms in general, prompting them to provide more detailed information in their reports, indirectly affecting the 
disclosure of financial instruments. Therefore, our fourth hypothesis is: Hypothesis $4\left(\mathrm{H}_{4}\right)-$ There is a positive relationship between presence in a regulated sector and the level of disclosure.

According to Khanna, Palepu \& Srinivasan (2004), the disclosure level required in the American capital market is high. For dual-listed companies, the need to report more comprehensive information to the American market can carry over to their accounting reports in Brazil, leading to our final hypothesis: Hypothesis $5\left(\mathrm{H}_{5}\right)$ - Companies with a longer history of issuing accounting reports in the American market have higher disclosure levels than those that just recently started issuing reports to both markets.

\section{DATA AND METHODS}

\subsection{SELECTING THE COMPANIES AND OBTAINING THE REPORTS}

For the Brazilian capital market, we analyzed the Standardized Financial Statements (Demonstrações Financeiras Padronizadas - DFP), while for the American market we examined the 20F forms, which are prepared according to the standards of the FASB. Foreign companies that issue American Depositary Receipts (ADRs) at level II or III must disclose accounting information using Form 20F. Therefore, the reason to focus here on Brazilian firms that issue ADRs is the fact they have the obligation to publish financial statements according to two sets of standards.

Because this study started in January 2008, the most recent 20F forms available for download were those for the 2006 fiscal year. This also is coherent with the analysis of data from a period before convergence of standards. We decided to study the financial statements published during five years, in line with several other studies (e.g., Wallace, 1988; Coy \& Dixon, 2004; Eijffinger \& Geraats, 2006).

To form the sample, we first chose Brazilian firms with some type of ADR listed for trading on the New York Stock Exchange (NYSE). For this purpose, we searched the CVM database (CVM, 2008b) and identified 102 records of Brazilian firms issuing some type of security in the American market. We then submitted these 102 records to a three-step filtering process: i) exclusion of financial institutions, as such companies are not the aim of this study; ii) exclusion of firms other than those issuing level II or III ADRs; and iii) exclusion of firms not required to issued Form 20F for all the years from 2002 to 2006, in the last case verified by analysis of the NYSE website (NYSE, 2008). The final sample consisted of 24 firms, as indicated in Appendix A. 
The 20F forms of the selected firms were obtained from NYSE (2008) and SEC (2008). In turn, the DFP were obtained from the obtained either from the websites of the companies' themselves or the CVM (2008b). Through this process, we collected 240 annual reports, distributed as follows: five reports (one for each year) according to Brazilian standards for each of the 24 selected companies; and five reports (also for each of the five years) prepared according to American standards for each of the 24 firms.

\subsection{DISCLOSURE INDEX AND DATA TREATMENT}

The analysis of the disclosure level of financial instruments in the selected reports was based on the disclosure index used previously by Lopes \& Rodrigues (2007), applied to Portuguese companies listed on the Lisbon Stock Exchange. That index measures the disclosure of financial instruments according to the IAS 32 and IAS 39 (International Accounting Standards 32 and 39) for 2000, analyzed through a list of 54 questions.

In 2000, the procedures for disclosure of financial instruments in line with international standards were regulated by IAS 32 and IAS 39. For our study period, these procedures were regulated by IFRS 7, requiring some modifications in that data collection instrument. Therefore, we analyzed that questionnaire in light of IFRS 7, resulting in a new instrument composed of 45 questions, contained in Appendix B (also indicating the excluded questions). The reduction in the number or questions was due to the changes in the international standards. For example, IFRS 7 no longer has the requirement for disclosure of the fair value of derivatives during the year, so that question was excluded from the original instrument.

The adapted questionnaire has the same characteristics as that prepared by Lopes \& Rodrigues (2007), namely: i) all variables are dichotomous (dummies); ii) equal weighting of all the questions (assuming that all the components have equal importance for inclusion in the statements); and iii) adjustment for items no longer applicable (to prevent the index from being biased due to companies not disclosing information no longer required).

To achieve consistency in application of the mentioned instrument, we prepared a working paper for consultation during the analysis of the reports, composed of clarifications about what should be present regarding each item of the questionnaire. For example, for the question on the accounting policies adopted for financial assets available for sale, we assigned points only when the company disclosed a specific accounting policy for this type of asset. We considered it to be not applicable when the company stated it did not trade in such instruments (or did not own any on the date of the analysis). Another example involves the type of hedging policy adopted by the company. In this case, for instance, Vale do Rio Doce 
disclosed on its 20F for 2006 that none of its financial instruments were for the purpose of hedging risk, so for the $20 \mathrm{~F}$ for 2006 , we considered that item as not applicable. But on the company's DFP for the same year, there was no mention of this fact, so we considered that item as not being disclosed.

Based on the content analysis using the data collection instrument, we assigned scores, representing "a quantitative assessment of the disclosure practices of the companies. They are not a qualitative indicator of the value of this information" (Khanna, Palepu \& Srinivasan, 2004, p. 482). Since all the questions are dichotomic, when the report satisfied a certain item we assigned the value of 1 to the variable, and 0 otherwise. Equation 1 below shows how the scores were calculated for each firm.

$$
S=\sum_{i=1}^{n} d_{i} \quad \text { (1) } \quad T=\sum_{i=1}^{n} q_{i} \quad \text { (2) } \quad \text { Indice }=\frac{S}{T} \times 100
$$

Where:

i: Starting number for the questions of the instrument to be verified;

$\mathrm{n}$ : Ending number (45 in this case) of the summation;

$\mathrm{d}_{\mathrm{i}}$ : The disclosure of each item of the instrument ( 1 if disclosed and 0 if not);

T: Total number of questions applicable to each firm;

Index: Disclosure index of the firm in a determined period.

Chart 2: Equations for calculation of the disclosure index

Source: Based on Lopes \& Rodrigues (2007).

We calculated the total of applicable questions according to Equation 2, also shown in Chart 1, and then computed the disclosure index of each firm according to Equation 3 in the chart.

We measured the size of the companies by the natural logarithm of total assets (figures obtained from the Economática database). This variable consists of the value of all the assets and rights held by the company in each year analyzed. We used a dummy variable for the level of corporate governance, assigning a value of 1 for firms listed for trading in any of the three enhanced governance segments of the BM\&FBovespa and 0 for firms not so listed. Likewise, we used a dummy variable for firms in regulated sectors (telecommunications, electricity and oil \& gas), assigning a value of 1 to these firms and 0 for others. Finally, we 
used a dummy variable regarding issuance of ADRs, assigning a value of 0 to firms that only issued ADRs after 1999 and 1 to those with a longer tradition of issuing those securities.

\subsection{TESTS OF THE HYPOTHESES}

Since the first hypothesis involves a bivariate analysis, we tested it based on pairwise comparison of the means. To test $\mathrm{H}_{2}, \mathrm{H}_{3}, \mathrm{H}_{4}$ and $\mathrm{H}_{5}$, we performed regression analysis with panel data, which allows combining cross-sectional data with time series (Hill, Griffiths \& Judge, 2003). According to Duarte, Lamounier \& Takamatsu (2007), the three most commonly used panel data models are the apparently unrelated regression model, the fixed effects model and the random effects model. For this article we chose the fixed effects model between companies and year, by which the response parameters are constant for all the firms and also for all the time periods (Duarte, Lamounier \& Takamatsu, 2007). Equation 2 below describes the model used (Model 1).

$$
\operatorname{DiscDFP}_{i t}=\beta_{0}+\beta_{1} \operatorname{LnTA}_{i t}+\beta_{2} \operatorname{CorpGov}_{i t}+\beta_{3} \operatorname{RegSect}_{i t}+\beta_{4} \operatorname{TimeADR}_{i t}+\varepsilon
$$

Where:

DiscDFP: Disclosure index of the DFP;

The subscripts i and t: Represent the firm and time period, respectively;

LnTA: Natural log of total assets;

CorpGov: Whether or not belonging to an enhanced corporate governance trading segment (dummy);

RegSect: Whether or not belonging to a regulated sector (dummy);

TimeADR: Issuer of ADRs since before 1999 or not (dummy);

$\beta_{0} ; \beta_{1} ; \beta_{2} ; \beta_{3} ; \beta_{4}$ : Represent the model parameters;

$\varepsilon:$ Represents the error term of the regression.

The second model proposed (Model 2), similar to the first, is represented by Equation 3 below, the only difference being the dependent variable, which is the disclosure index for Form 20F.

$\operatorname{Disc}_{20 F_{i t}}=\beta_{0}+\beta_{1} \operatorname{LnTA}_{i t}+\beta_{2} \operatorname{CorpGov}_{i t}+\beta_{3}$ RegSect $_{i t}+\beta_{4}$ TimeADR $_{i t}+\varepsilon$

Where:

Disc20F: Disclosure index of Form 20F; 
Other variables: Identical to Equation 2.

To complement the analysis — to check for the existence of factors that could influence the differences observed between the level of disclosure in the reports - we formulated a third model (Model 3) for analysis, described in Equation 4.

$\left(\operatorname{Disc20F}_{i t}-\right.$ DiscDFP $\left._{i t}\right)=\beta_{0}+\beta_{1}$ LnTA $_{i t}+\beta_{2} \operatorname{CorpGov}_{i t}+\beta_{3} \operatorname{RegSect}_{i t}+\beta_{4} \operatorname{TimeADR}_{i t}+\varepsilon(4)$

Where:

(Disc20F - DiscDFP): Difference between the disclosure indexes for Form 20F and DFP;

Other variables: Identical to Equations 2 and 3.

The idea behind the last model, considering the differences between the disclosure levels to the American and Brazilian markets, is to identify possible characteristics of companies associated with a higher/lower difference between the content of the reports provided to the two capital markets.

\section{RESULTS}

\subsection{ANALYSIS OF THE DISCLOSURE INDEXES}

After analyzing the accounting reports, we obtained 240 disclosure indexes. Table 1 presents an exploratory analysis of the scaled variables.

TABLE 1 - EXPLORATORY ANALYSIS OF THE INDEXES OBTAINED AND THE SIZE OF THE COMPANIES

\begin{tabular}{|l|l|l|l|l|l|}
\hline \multicolumn{1}{|c|}{ Variable } & N & Minimum & Maximum & Mean & Std. Dev. \\
\hline DisclDPF (\%) & & & & & \\
\hline Discl20F (\%) & & & & & \\
\hline LnTA & & & & & \\
\hline
\end{tabular}

Notes: Based on the Kolmogorov-Smirnov test, at 5\% significance, there was no evidence of nonnormality of the frequency distribution of the variables. DisclDPF - level of disclosure in the DPF; Discl20F - level of disclosure in the $20 \mathrm{~F}$

LnTA - natural logarithm of total assets

Source: Prepared by the authors.

Table 1 shows that no company, either for the Brazilian or American market, had a disclosure index greater than $75 \%$. In relation to each of the questions on the data collection instrument, we calculated the frequency of disclosure, from which we constructed the chart in 
Appendix C, which describes the points where the disclosure practices of Brazilian firms depart the most from IFRS 7.

As indicated in Appendix C, although the disclosure requirements of Form 20F are nearer the international requirements, the two types of reports present points of deficiency in relation to the international standards (which is coherent with the results of Table 1). Perhaps from investors' standpoint, for example, the disclosure of accounting policies for assets/liabilities held for trading is not as relevant as the presentation of a sensitivity analysis referring to interest rate risk. In other words, depending on the user of accounting information, failure to satisfy some items required by international standards may not have a great impact, but we assume that if the company has an adequate disclosure level, this care will assure the supply of relevant information to the different types of users, since each one might be more interested in a specific topic. This information can even be extended to disclosure of items that are not mandatory (voluntary disclosure).

Table 2 below shows the average disclosure indexes by type of report analyzed and by period.

Table 2: Differences of the means of the disclosure indexes

\begin{tabular}{|lllllll|}
\hline Variable & $\mathbf{2 0 0 2}$ & $\mathbf{2 0 0 3}$ & $\mathbf{2 0 0 4}$ & $\mathbf{2 0 0 5}$ & $\mathbf{2 0 0 6}$ & Média \\
\hline (1) Discl. DFP & 32,34 & 37,11 & 38,43 & 39,91 & 41,98 & 37,95 \\
(2) Discl. 20F & 47,49 & 50,68 & 54,21 & 55,15 & 55,74 & 52,65 \\
(3) Difference (2 - 1) & $15,15^{* * *}$ & $13,58^{* * *}$ & $15,78^{* * *}$ & $15,24^{* * *}$ & $13,76^{* * *}$ & $14,70^{* * *}$ \\
Difference in \% (3 / 1) & 46,85 & 36,59 & 41,08 & 38,18 & 32,78 & 39,10 \\
Correlation (1 e 2) & $0,625^{* * *}$ & $0,764^{* * *}$ & $0,641^{* * *}$ & $0,611^{* * *}$ & $0,526^{* *}$ & $0,691^{* * *}$ \\
No Observations & 24 & 24 & 24 & 24 & 24 & 120 \\
\hline
\end{tabular}

Notes: DisclDPF - level of disclosure in the DPF; Discl20F - level of disclosure in the 20F; Difference difference between the disclosure in the Form 20F and DPF; Difference in \% - how much the difference between the level of disclosure of the reports represents over the disclosure index of the DFP; Correlation Pearson's correlation coefficient between the DFP and 20F disclosure levels.

$* * *$ significant at $0.1 \%$; ** significant at $1 \%$; $*$ significant at $5 \%$.

Source: Prepared by the authors.

As shown in Table 2, the average disclosure index during the five years studied increased steadily for the two types of reports. Also, during the entire period, the disclosure level of the firms' $20 \mathrm{~F}$ forms was greater than that of their DFP reports, by an average of $39 \%$. A pairwise $\mathrm{t}$-test indicated that the difference between the two accounting reports (DFP x 20F) was statistically significant at $0.1 \%$ in all years (even for the same company), 
indicating no rejection of $\mathrm{H}_{1}$, a result in line with previous findings in the literature. The correlation between the reports was also significant and positive. In other words, there appears to be a tendency for firms with more complete reports in one market also to publish more complete reports in the other market.

\subsection{ANALYSIS OF THE POSSIBLE DETERMINANTS OF THE DISCLOSURE LEVEL}

To analyze the hypotheses considering the joint effect of all the variables and their respective influence on the other variables, we performed regression of panel data with fixed effects for year and cross-section. The results are shown in Table 3 below.

TABLE 3: RESULTS OF THE REGRESSION WITH PANEL DATA

\begin{tabular}{|l|l|}
\hline Hyp. & Variable \\
\hline- & \\
\hline 1 & Constant \\
\hline 2 & LnTA \\
\hline 3 & CorpGov \\
\hline 5 & RegSect \\
\hline & TimeADR \\
\hline & N (observ.) \\
\hline & Adjusted R ${ }^{2}$ (model) \\
\hline & p-value (model) \\
\hline
\end{tabular}

Notes: Equations analyzed:

(...)

Where: DiscDFP: DFP disclosure index; Disc20F: 20F disclosure index; (DiscDFP - Disc20F): difference between the DFP and 20F disclosure indexes; the subscripts $\mathrm{i}$ and $\mathrm{t}$ represent the firm and time period, respectively; LnTA: natural logarithm of total assets; CorpGov: whether or not the firm's securities are listed for trading in a segment requiring enhanced corporate governance (dummy); RegSect: whether or not the firm is in a regulated sector (dummy); TimeADR: issued ADRs before 1999 or not (dummy); B... represent the parameters of the model; e: represents the error term of the regression.

$* * *$ significant at $0.1 \%$; ** significant at $1 \%$; $*$ significant at $5 \%$.

Source: Prepared by the authors.

We first analyzed the residuals of the regression. For Models 1 and 2 these presented the following characteristics (Hair et al., 2005): i) they were random variables with mean equal to zero; ii) they were normally distributed (Jarque-Bera test); iii) they had independent distribution (absence of patterns); and iv) they had constant variance (when necessary, we performed correction by means of the White test for heteroskedasticity). The VIF test 
(variance inflation factor) did not indicate multicollinearity. The analysis of the p-value (referring to the F-test) of each to the two models also showed they are valid because they are lower than 0.05 . The results were different for the third model, but this did not fail to imply interesting results for the study.

Based on the results shown in Table 3, hypothesis 2, that there is a positive relationship between the size of the firms and their disclosure level, was corroborated for the two types of reports, because the p-value is below 0.05 . In other words, the larger the firm, the higher the level of disclosure of financial instruments tends to be. The theory according to which larger companies generate more detailed information with lower unit costs appears to hold for our sample of companies.

The hypothesis that listing in a trading segment requiring higher corporate governance is related to greater disclosure levels $\left(\mathrm{H}_{3}\right)$ was not corroborated, but it was also not refuted. The betas found were negative for the two types of report, indicating an inverse relationship in this case. In other words, companies with securities listed for trading in differentiated corporate governance segments tend to have lower average disclosure indexes. This goes against the theoretical expectation, but the result was not statistically significant.

On this matter, it should be considered that all the companies analyzed were issuers of ADRs, for which reason they already had to meet a higher standard of disclosure. This might explain this counterintuitive result for listing in enhanced governance segments. Still, a positive but not significant result would not be as surprising as the negative coefficients found. Regarding the fourth hypothesis, it was also confirmed in this initial analysis. In other words, companies in regulated sectors tended to have higher disclosure levels, at 0.05 significance.

For the DFP reports, $\mathrm{H}_{5}$ was not rejected, and the hypothesis was also confirmed for the Form 20F reports, but without significance. Therefore, the time of issuing ADRs was positively related to the quality of the accounting reports measured by the level of disclosure of financial instruments. Since the DFP reporting rules are not as exigent as those for Form 20F, we believe firms listed longer on the NYSE tended to supply more detailed information on their DFP than those listed on that exchange more recently, which can indicate a learning effect. In other words, firms with more experience of issuing accounting reports to the American market appear to have a tendency to disclose more complete information to the Brazilian market, through a carry-over effect. 


\section{DISCUSSION AND FINAL CONSIDERATIONS}

In light of the context of convergence of accounting standards in Brazil, our main objective was to analyze the level of disclosure of financial instruments of Brazilian companies in their accounting reports to two different capital markets: the Brazilian and American. We found that the accounting reports of the Brazilian firms in our sample fell shy to different degrees from the requirements of the IASB for disclosure of financial instruments. This difference of degree (statistically significant) occurred in relation to the two markets, with the Form 20F reports departing less from the IASB requirements than the DFP reports.

None of the 240 accounting reports analyzed were prepared according to the international standards, so the firms did not have an obligation to meet those requirements. Therefore, the differences found between the standards for preparation of the two reports (Brazilian and American) and the international standards (IAS/IFRS) at least give an indication of what can be expected after the period of convergence: more detailed information after the requirement to meet the IFRS.

Seeking to establish possible explanations for the results obtained, we tested four hypotheses, and the evidence indicates that the size of firms - measured by the value of their total assets — had a positive and statistically significant relationship with the disclosure level. This result is aligned with the theory and also with the results of previous studies. However, unlike expected, the fact of firms being listed for trading in enhanced corporate governance segments of the BM\&FBovespa presented a negative relation with the level of disclosure, although it was not significant for the firms analyzed. The consideration of the existence of a trend for create a globally uniform governance structure, with respect to functional convergence, was not borne out because the firms with higher corporate governance levels in Brazil were those with the lowest indexes of disclosure of financial instruments.

In contrast, the fact of being in a regulated sector was positively and significantly associated with the disclosure level. Finally, in relation to the last hypothesis tested, there was a positive influence of the time listed on the NYSE on the quality of disclosure. These two results suggest a learning effect: the experience of heightened reporting requirements, whether from regulators or due to the time of issuing reports to the American market, appears to prompt companies indirectly to provide more detailed information on financial instruments in their accounting reports. Hence, for the firms studied in this article, the sector of activity is a better indicator of more complete accounting reports that being listed in an enhanced corporate governance trading segment. 
It should be noted that there are no economic incentives in Brazil for firms to provide more disclosure in financial statements, and this could have been a factor contributing to the low level of disclosure found in accounting reports. This observation is even more justified when noting that these firms have the necessary information (because they report it in their 20F forms) but do not always disclose it in full to the Brazilian market.

Two limitations of the present study should be noted, related to the selection of companies: i) the exclusion of financial institutions from the sample; and ii) the inclusion of only Brazilian companies with ADRs traded on the NYSE, belonging to different sectors of the economy.

Nevertheless, we believe this study contributes to research on the challenges posed by convergence of accounting standards, which is a relevant issue in both the corporate and academic spheres. We also expect this study will contribute to future research on disclosure indexes and their association with other variables. Besides this the results can serve as a base for revision and/or complementation of Brazilian legislation on financial instruments, because our findings allow an estimate of the level of convergence both of Brazilian and American accounting standards in relation to international ones.

Specifically we recommend future studies in the following aspects: i) extension of the scope to cover the disclosure of financial instruments by Brazilian financial institutions with securities listed on the NYSE; ii) extension of the study to the Brazilian scenario, to investigate the informational value attributed to the items present in the data collection instrument for different types of users of accounting information; iii) analysis of the distance of the accounting reports of Brazilian companies in relation to other IASB standards; iv) analysis of whether or not accounting reports contain voluntary disclosures, and if so, to what extent; and v) analysis of the variables used in this study with data after the convergence period.

\section{REFERENCES}

AGUIAR, A. B.; HIRANO, A. Os impactos do Fair Value como base de valor para instrumentos financeiros derivativos na atual estrutura da contabilidade: um enfoque normativo. In: ENCONTRO NACIONAL DA ASSOCIAÇÃO NACIONAL DE PÓSGRADUAÇÃO E PESQUISA EM ADMINISTRAÇÃO, 27., 2003, Atibaia. Anais... Atibaia: ANPAD, 2003.

AKHTARUDDIN, M. Corporate mandatory disclosure practices in Bangladesh. The International Journal of Accounting, v. 40, n. 4, p. 399-422, 2005. 
ALSAEED, K. The association between firm-specific characteristics and disclosure: the case of Saudi Arabia. Managerial Auditing Journal, v. 21, n. 5, p. 476-496, 2006.

BHAMORNSIRI, S.; SCHROEDER, R. G. The disclosure of information on derivatives under SFAS no. 133: evidence from the dow 30. Managerial Auditing Journal, v, 19, n. 5 , p. 669-680, 2004.

BOVESPA - Bolsa de Valores de São Paulo. Empresas / Para Investidores / Empresas Listadas. Disponível em: <www.bovespa.com.br>. Acesso em: 1 maio 2008.

BUSHMAN, R. M.; PIOTROSKI, J. D.; SMITH, A. J. What determines corporate transparency? Journal of Accounting Research, v. 42, n. 2, p. 207-252, maio 2004.

CARVALHO, N. M. "Hedge Accounting" de ativos financeiros segundo o pronunciamento SFAS 133: análise dos critérios de reconhecimento de receita em face do princípio da realização da receita e da confrontação das despesas. 2002. Dissertação (Mestrado em Controladoria e Contabilidade: Contabilidade) - Faculdade de Economia, Administração e Contabilidade, Universidade de São Paulo, São Paulo: FEA/USP, 2002.

COFFEE, J. C. The future as history: the prospectes for global convergence in corporate governance and its implications. The Social Science Research Network Electronic Paper Collection.1999. Disponível em: <http://papers.ssrn.com/>. Acesso: 30 ago. 2008.

COSTA JUNIOR, J. V. Uma avaliação do nível de evidenciação das companhias abertas, no Brasil, no tocante aos instrumentos financeiros. Revista Contabilidade e Finanças, v. 14, n. 32, p. 23-39, maio/ago. 2003.

COSTA, F. M.; GOLDNER, F.; GALDI, F. C. Análise dos fatores que influenciam no disclosure dos maiores bancos brasileiros. In: CONGRESSO USP DE CONTROLADORIA E CONTABILIDADE, 7., 2007, São Paulo. Anais... São Paulo: USP, 2007.

COY, D.; DIXON, K. The public accountability index: crafting a parametric disclosure index for annual reports. The British Accounting Review, v. 36, n. 1, p. 79-106, 2004.

CVM - Comissão de Valores Mobiliários. Apresentação de informações sobre instrumentos financeiros derivativos em nota explicativa às informações trimestrais - ITR. Deliberação CVM n' 550, de 17 de Outubro de 2008a. Disponível em:

$<$ http://www.cvm.gov.br/port/snc/Normas.asp $>$. Acesso em: 15 nov. 2010.

CVM - Comissão de Valores Mobiliários. Estudo sobre as diferenças e similaridades das normas internacionais de contabilidade (IFRS) e as normas e práticas contábeis brasileiras.

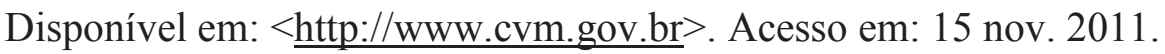


CVM - Comissão de Valores Mobiliários. Elaboração e divulgação das demonstrações financeiras consolidadas, com base no padrão contábil internacional emitido pelo International Accounting Standards Board - IASB. . Instrução no 457, de 13 de Julho de

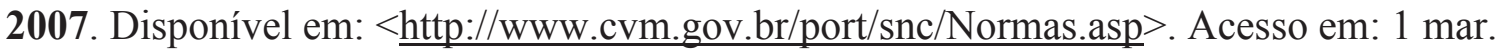
2010.

CVM - Comissão de Valores Mobiliários. ITR, DFP, IAN, IPE e outras informações.

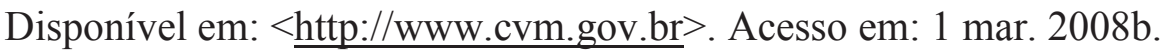

DARÓS, L. L.; BORBA, J. A. Evidenciação de instrumentos financeiros derivativos nas demonstrações contábeis: uma análise das empresas brasileiras. Revista Contabilidade e Finanças, v. 16, n. 39, p. 68-80, set./dez. 2005.

DARÓS, L. L.; BORBA, J. A.; ABREU, A. F. Evidenciação de instrumentos financeiros derivativos nas demonstrações contábeis: uma comparação entre as informações divulgadas no Brasil e nos Estados Unidos... In: ENCONTRO NACIONAL DA ASSOCIAÇÃO NACIONAL DE PÓS-GRADUAÇÃO E PESQUISA EM ADMINISTRAÇÃO, 29., 2005. Anais... Brasília: ANPAD, 2005.

DUARTE, P. C.; LAMOUNIER, W. M.; TAKAMATSU, R. T. Modelos econométricos para dados em painel: aspectos teóricos e exemplos de aplicação à pesquisa em contabilidade... In: CONGRESSO USP DE CONTROLADORIA E CONTABILIDADE, 7., 2007, São Paulo. Anais Eletrônicos... São Paulo: USP, 2007.

ECONOMÁTICA - Banco de Dados Economática. Economatica: tools for investiment analysis. Número de série: 8900510565. Versão: 2007Apr03. Disponível em:

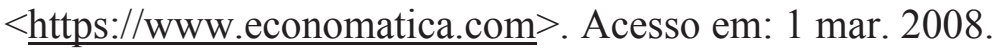

EIJFFINGER, S. C. W.; GERAATS, P. M. How transparent are central banks? European Journal of Political Economy, v. 22, n. 1, p. 1-21, mar. 2006.

GALLON, A. V. Evidenciação contábil nos relatórios da administração das empresas participantes dos níveis de governança da BOVESPA. 2006. 150 f. Dissertação (Mestrado em Ciências Contábeis) - Programa de Pós-Graduação em Ciências Contábeis, Centro de Ciências Sociais Aplicadas da Universidade Regional de Blumenau, Blumenau: FURB, 2006.

HAIR, J. F. et al. Análise multivariada de dados. Tradução de Adonai Schulup Sant'Anna e Anselmo Chaves Neto. 5. ed. Porto Alegre: Bookman, 2005.

HERNANDEZ, F. G. H. Derivatives and the FASB: visibility and transparency? Critical Perspectives on Accounting. vol. 14, n. 8, p. 777-789, 2003.

HILL, R. C.; GRIFFITHS, W. E.; JUDGE, G. G. Econometria. Tradução de Alfredo Alves de Faria. 2. ed. São Paulo: Saraiva, 2003. 
HO, S. S. M.; WONG, K. S. A study of the relationship between corporate governance structures and the extent of voluntary disclosure. Journal of International Accounting, Auditing and Taxation, v. 10, n. 2, p. 139-156, 2001.

HORNGREN, C. T. Disclosure: 1957. The Accounting Review, v. 32, n. 4, p. 598-604, out. 1957.

IASB - International Accounting Standards Board. IASB and the IASC foundation: who we are and what we do. Disponível em: $<\underline{\mathrm{http}}$ ://www.ifrs.com/updates/iasb/about the iasb.html $>$. Acesso em: 1 mar. 2008a.

IASB - International Accounting Standards Board. IFRS 7 - Financial Instruments: disclosure. In: International Financial Reporting Standards (IFRSs): including International Accounting Standards (IASs) and Interpretations as approved at 1 january 2008. p. 747-814. Disponível em:

$<$ http://ec.europa.eu/internal_market/accounting/docs/consolidated/ifrs7_en.pdf $>$. Acesso em: 1 mar. 2008b.

IASB/CFC/CPC. Padronização de normas contábeis. Memorando de entendimentos entre a Junta de Normas Internacionais de Contabilidade (IASB), o Conselho Federal de Contabilidade (CFC) e o Comitê de Pronunciamentos Contábeis (CPC) para intensificar a padronização das normas contábeis. Assinado em 28 jan. 2010.

IBGC - Instituto Brasileiro de Governança Corporativa. Governança corporativa: código das melhores práticas de governança corporativa, 2003. Disponível em: $<\underline{w w w . i b g c . o r g . b r}>$. Acesso em: 1 mar. 2008.

IUDÍCIBUS, S.; MARTINS, E.; CARVALHO, L. N. Contabilidade: aspectos relevantes da epopéia de sua evolução. Revista Contabilidade e Finanças, v. 16, n. 38. p. 7-19, maio/ago. 2005.

KHANNA, T.; PALEPU, K. G.; SRINIVASAN, S. Disclosure practices of foreign companies interacting with U.S. markets. Journal of Accounting Research, v. 42, n. 2, p. 509-525, maio 2004.

LAMBERT, R.; LEUZ, C.; VERRECCHIA, R. E. Accounting information, disclosure, and the cost of capital. Journal of Accounting Research, v. 45, n. 2, p. 385-420, maio 2007.

LEUZ, C.; VERRECCHIA, R. E. The economic consequences of increased disclosure. Journal of Accounting Research, v. 38, p. 91-124, supplement: studies on accounting information and the economics of the firm, 2000.

LEVINE, R.; LOAYZA, N.; BECK, T. Financial intermediation and growth: causality and causes. Journal of Monetary Economics, v. 46, n. 1, p. 31-77, 2000. 
LIMA, G. A. S. F. et al. Governança Corporativa. In: LIMA, I. S.; LIMA, G. A. S. F.; PIMENTEL, R. C. Curso de mercado financeiro: tópicos especiais. São Paulo: Atlas, 2006. p. 536-551.

LOPES, A. B.; ALENCAR, R. C. Disclosure and cost of equity capital in emerging markets: the brazilian case. The International Journal of Accounting, v. 45, n. 4, p. 443-464, dez. 2010 .

LOPES, A. B.; CARVALHO, L. N. G. Contabilização de operações com derivativos: uma comparação entre o SFAS n ${ }^{\circ} 133$ e o arcabouço emanado pelo COSIF. Caderno de Estudos, n. 20, jan./abr. 1999.

LOPES, A. B.; LIMA, I. S. Disclosure de operações com derivativos: panorama internacional. Caderno de Estudos, v. 10, n. 18, maio/ago. 1998.

LOPES, A. B.; MARTINS, E. Teoria da contabilidade: uma nova abordagem. São Paulo: Atlas, 2005.

LOPES, P. T.; RODRIGUES, L. L. Accounting for financial instruments: an analysis of the determinants of disclosure in the portuguese stock exchange. The Journal of Accounting. v. 42, n. 1, p. 25-56, 2007.

LOVE, I. Financial development and financing constraints: international evidence from the structural investment model. The Review of Financial Studies, v. 16, n. 3, p. 765-791, Autumn 2003.

LUCRO da Metlife cai no trimestre com perdas em derivativos. Valor on-line, 9 fev. 2011. Disponível em: <www.valoronline.com.br>. Acesso em: 16 fev. 2011.

MALACRIDA, M. J. C.; YAMAMOTO, M. M. Governança corporativa: nível de evidenciação das informações e sua relação com a volatilidade das ações do Ibovespa.

Revista Contabilidade e Finanças, edição comemorativa, p. 65-79, set. 2006.

MURCIA, F. D; SANTOS, A. Regulação contábil e divulgação de informações de operações com instrumentos financeiros derivativos: análise do impacto da CVM... In: ENCONTRO NACIONAL DA ASSOCIAÇÃO NACIONAL DE PÓS-GRADUAÇÃO E PESQUISA EM ADMINISTRAÇÃO, 33., São Paulo, 2009. Anais... São Paulo: ANPAD, 2009.

NASER, K.; NUSEIBEH, R. Quality of financial reporting: evidence from the listed Saudi nonfinancial companies. The International Journal of Accounting, v. 38, n. 1, p. 41-69, 2003.

NYSE - New York Stock Exchange. Listings Directory. Latin America. Brazil. Disponível em: $<$ http://www.nyse.com $>$. Acesso em: 1 mar. 2008. 
POSHAKWALE, S.; COURTIS, J. K. Disclosure level and cost of equity capital: evidence from the banking industry. Managerial and Decision Economics, v. 26, n. 7, p. 431-444, 2005 .

PWC - PRICEWATERHOUSECOOPERS Auditores Independentes. Expositores: MIRON, Paulo Sérgio e ANDRADE, Rosali A. Argolo. Contabilização e avaliação de instrumentos financeiros derivativos. In: Conselho Regional de Contabilidade do Estado de São Paulo, Instituto Brasileiro de Contadores. Temas contábeis relevantes. SILVA JÚNIOR, José Barbosa da (Coord,). São Paulo: Atlas, 2000. Cap. 8.

SAITO, R.; SCHIOZER, R. F. Uso de derivativos e gerenciamento de risco em empresas nãofinanceiras: uma comparação entre evidências brasileiras e internacionais. In: ENCONTRO NACIONAL DA ASSOCIAÇÃO NACIONAL DE PÓS-GRADUAÇÃO E PESQUISA EM ADMINISTRAÇÃO, 28., 2004. Anais... Curitiba: ANPAD, 2004. 1 CD-ROM.

SEC - Securities and Exchange Commission. Filings \& Forms: Search for Company Filings: Companies \& Other Filers. EDGAR database . Disponível em:

$<$ http://www.sec.gov/edgar.shtml $>$. Acesso em: 1 mar. 2008.

WALLACE, P. W.; WILLIAMS, A. G. Accounting for derivatives: the latest changes affecting financial institutions. Bank Accounting \& Finance, v. 15, n. 3, 2002.

WALLACE, R. S. O. Corporate financial reporting in Nigeria. Accounting and Business Research, v. 18, n. 72, p. 352-362, 1988. 


\section{APPENDIX A: COMPANIES COMPOSING THE SAMPLE}

\begin{tabular}{|c|c|c|c|}
\hline No. & Company Name & Level - ADR & $\begin{array}{c}\text { Total Consolidated Assets } \\
\text { (R\$ thousand - Dec. 31, 2007) }\end{array}$ \\
\hline 1 & Cia. de Bebidas das Américas & Nivel II & $35.645 .114,00$ \\
\hline 2 & Aracruz Celulose S.A. & Nivel III & $9.577 .120,00$ \\
\hline 3 & Braskem S.A. & Nivel II & $16.304 .322,00$ \\
\hline 4 & Brasil Telecom S.A. & Nivel II & $15.997 .784,00$ \\
\hline 5 & Brasil Telecom Part. S.A. & Nivel II & $17.793 .790,00$ \\
\hline 6 & Cia. Brasileira de Distribuição & Nivel II & $11.672 .273,00$ \\
\hline 7 & Cia. Energética de Minas Gerais & Nivel II & $23.208 .716,00$ \\
\hline 8 & Cia. Paranaense de Energia & Nivel III & $11.934 .623,00$ \\
\hline 9 & Empresa Bras. de Aeronáutica & Nivel III & $16.291 .755,00$ \\
\hline 10 & Gerdau S.A. & Nivel II & $26.929 .543,00$ \\
\hline 11 & Perdigão S.A. & Nivel III & $4.829 .416,00$ \\
\hline 12 & Petróleo Brasileiro S.A. & Niveis II e III & $210.538 .129,00$ \\
\hline 13 & Sadia S.A. & Nivel II & $7.576 .351,00$ \\
\hline 14 & SABESP & Nivel III & $17.999 .953,00$ \\
\hline 15 & Cia. Siderúrgica Nacional & Nivel II & $25.028 .301,00$ \\
\hline 16 & Telecomunicações de São Paulo & Nivel II & $18.145 .880,00$ \\
\hline 17 & Tim Part. S.A. & Nivel II & $14.200 .105,00$ \\
\hline 18 & Telemig Celular Part. S.A. & Nivel II & $1.988 .240,00$ \\
\hline 19 & Tele Norte Celular Part. S.A. & Nivel II & $645.877,00$ \\
\hline 20 & Tele Norte Leste Part. S.A. & Nivel II & $27.790 .611,00$ \\
\hline 21 & Ultrapar Part. S.A. & Nivel III & $3.849 .844,00$ \\
\hline 22 & Vivo Part. S.A. & Nivel II & $17.542 .077,00$ \\
\hline 23 & Votorantim Celulose e Papel S.A. & Nivel III & 10.206.817,00 \\
\hline 24 & Cia. Vale do Rio Doce & Niveis II e III & $123.008 .906,00$ \\
\hline
\end{tabular}




\section{APPENDIX B: DATA COLLECTION INSTRUMENT USED IN THE STUDY}

\begin{tabular}{|c|c|}
\hline & Score (if disclosed and applicable) \\
\hline \multicolumn{2}{|l|}{ Financial Instruments - Accounting policies } \\
\hline 1 Held for trading assets/liabilities & 1 \\
\hline 2 Held-to-maturity assets & 1 \\
\hline 3 Loans and receivables originated by the enterprise & 1 \\
\hline 4 Available-for-sale financial assets & 1 \\
\hline 5 Other financial liabilities & 1 \\
\hline 6 Trade date or settlement date & 1 \\
\hline \multicolumn{2}{|l|}{ Financial Instruments - Fair Value } \\
\hline 7 Fair value of assets and liabilities (grouped by classes) & 1 \\
\hline 8 Measurement method & 1 \\
\hline 9 Significant assumptions & 1 \\
\hline \multicolumn{2}{|l|}{ Financial Instruments - Risks } \\
\hline 10 Risk management policy & 1 \\
\hline 11 Monitoring and controlling policy & 1 \\
\hline 12 Segregation by risk types & 1 \\
\hline 13 Description of how those risks arises & 1 \\
\hline 14 Exposure to risk & 1 \\
\hline 15 Methods used to measure the risk & 1 \\
\hline \multicolumn{2}{|l|}{ Derivatives - Accounting Policies } \\
\hline 16 Objectives of holding or issuing derivatives & 1 \\
\hline 17 Accounting policies and methods adopted & 1 \\
\hline \multicolumn{2}{|l|}{ Derivatives - Hedging } \\
\hline 18 Hedging description & 1 \\
\hline 19 Financial instruments designated as hedging instruments & 1 \\
\hline 20 Fair values of those financial instruments & 1 \\
\hline 21 Nature of the risks being hedged & 1 \\
\hline 22 If hedge accounting is applicable & 1 \\
\hline 23 Type of hedge relationship adopted & 1 \\
\hline \multicolumn{2}{|l|}{ Derivatives - Fair value } \\
\hline 24 Measurement method & 1 \\
\hline 25 Significant assumptions & 1 \\
\hline \multicolumn{2}{|l|}{ Interest Rate Risk } \\
\hline 26 Sensitivity analysis & 1 \\
\hline 27 Methods and assumptions used in the sensitivity analysis & 1 \\
\hline \multicolumn{2}{|l|}{ Currency Rate Risk } \\
\hline 28 Sensitivity analysis & 1 \\
\hline 29 Methods and assumptions used in the sensitivity analysis & 1 \\
\hline \multicolumn{2}{|l|}{ Other Prices Risk } \\
\hline 30 Sensitivity analysis & 1 \\
\hline 31 Methods and assumptions used in the sensitivity analysis & 1 \\
\hline \multicolumn{2}{|l|}{ Credit risk } \\
\hline 32 Counterparties identification & 1 \\
\hline 33 Maximum amount of credit risk exposure (by class) & 1 \\
\hline 34 Analysis of the age of financial assets & 1 \\
\hline \multirow[t]{2}{*}{35 Criteria used to determine allowance } & 1 \\
\hline & Continua na próxima página \\
\hline
\end{tabular}


36 Significant concentration of credit risk

Continuação da página anterior

37 Description of the collateral policies

38 Information about the credit quality

Collateral

39 Terms and conditions (relative to its pledge or associated with its use)

40 Carrying amount (if pledged) or fair value (if held)

\section{Liquidity risk}

41 A maturity analyze, showing the remaining contractual maturities (time bands)

42 Description of how manages the liquidity risk

Other

43 Impairment losses

44 Criteria to determine that there is objective evidence that an impairment loss has occurred

45 Total interest income and total interest expense (separately)

Items excluded/adapted from the original questionnaire

Fair values and market values - Amount recognised in equity

Fair values and market values - Amount removed from equity

Unability of reliability in measurement - Financial assets description

Unability of reliability in measurement - Their carrying amount

Unability of reliability in measurement - Explanation of the reason

Unability of reliability in measurement - Range of estimates within which the fair value is likely to lie

Securitisation and repurchase agreements - Accounting policy

Securitisation and repurchase agreements - Nature and extent

Securitisation and repurchase agreements - Collateral

Securitisation and repurchase agreements - Whether the financial assets have been derecognised

Securitisation and repurchase agreements - Information about the key assumptions used in calculating the fair value of new and retained interests

Derivatives - Accounting policies - Financial controls (analisado na questão: 11 - Monitoring and controlling policy)

Derivatives - Risks - Principal, stated value, face value, notional value (adaptada)

Derivatives - Risks - Maturity (adaptada)

Derivatives - Risks - Weighted average/effective interest rate

Derivatives - Hedging - Accounting method (adaptada)

Future transactions hedging - The period in which forecasted transactions are expected to occur (resumida nas questões 22 e 23)

Future transactions hedging - The period they are expected to enter in income (resumida nas questões 22 e 23)

Cash-flow hedging - The amount recognised in equity (resumida nas questões 22 e 23)

Cash-flow hedging - The amount removed from equity and recognised in income (resumida nas questões 22 e 23)

Cash-flow hedging - The amount removed from equity and added to initial measurement of the acquisition cost (resumida nas questões 22 e 23)

Derivatives - Fair value - Fair value (analisada na questão 7)

Interest rate risk - Future changes in interest rates (analisada nas questões 26 e 27)

Interest rate risk - Maturity dates (analisada nas questões 26 e 27)

Other - In AFS, realized and unrealized gains/losses (separately)

Source: Lopes \& Rodrigues (2007), with adaptations. 
APPENDIX C: ANALYSIS OF ADHERENCE TO THE IASB STANDARDS

\begin{tabular}{|c|c|c|}
\hline Item of the data collection instrument & & \\
\hline & DFP & $20 \mathrm{~F}$ \\
\hline Policies on assets/liabilities held for trading & & \\
\hline Policies on assets held to maturity & & \\
\hline Policies on financial assets available for sale & & \\
\hline Presentation of the trade or settlement date of financial instrument & & \\
\hline $\begin{array}{l}\text { Significant assumptions adopted to calculate the fair value of financial } \\
\text { instruments in general }\end{array}$ & & \\
\hline Policies for monitoring and controlling risks of financial instruments & & \\
\hline Methods used to measure the risk of financial instruments & & \\
\hline $\begin{array}{l}\text { If hedge accounting is applicable to any of the transactions with financial } \\
\text { instruments }\end{array}$ & & \\
\hline Type of hedge relationship adopted & & \\
\hline Significant assumptions for calculating the fair value of derivatives & & \\
\hline Presentation of sensitivity analysis of interest rate risks & & \\
\hline $\begin{array}{l}\text { Relevant methods and assumptions used to analyze the sensitivity to interest rate } \\
\text { risks }\end{array}$ & & \\
\hline Presentation of sensitivity analysis of exchange rate risks & & \\
\hline $\begin{array}{l}\text { Relevant methods and assumptions used to analyze the sensitivity to exchange } \\
\text { rate risks }\end{array}$ & & \\
\hline Presentation of sensitivity analysis of other price risks & & \\
\hline $\begin{array}{l}\text { Relevant methods and assumptions used to analyze the sensitivity to other price } \\
\text { risks }\end{array}$ & & \\
\hline Maximum amount of credit risk exposure & & \\
\hline Analysis of maturities of financial instruments & & \\
\hline Description of the collateral policies adopted & & \\
\hline Presentation impairment losses & & \\
\hline $\begin{array}{l}\text { Criteria used to determine thee is objective evidence that an impairment loss has } \\
\text { occurred }\end{array}$ & & \\
\hline
\end{tabular}

* Quart. 1: Corresponds to the questions classified in the first quartile, representing questions with lower frequency of disclosure.

Source: Prepared by the authors 